\title{
Therapeutic concentration of morphine reduces oxidative stress in glioma cell line
}

\author{
M.B. Almeida ${ }^{1}$, A. Costa-Malaquias ${ }^{1}$, J.L.M. Nascimento ${ }^{2}$, K.R. Oliveira ${ }^{3}$, \\ A.M. Herculano ${ }^{3}$ and M.E. Crespo-López ${ }^{1}$ \\ ${ }^{1}$ Laboratório de Farmacologia Molecular, Instituto de Ciências Biológicas, Universidade Federal do Pará, Belém, PA, Brasil \\ ${ }^{2}$ Laboratório de Neuroquímica Molecular e Celular, Instituto de Ciências Biológicas, \\ Universidade Federal do Pará, Belém, PA, Brasil \\ ${ }^{3}$ Laboratório de Neuroendocrinologia, Instituto de Ciências Biológicas, Universidade Federal do Pará, Belém, PA, Brasil
}

\begin{abstract}
Morphine is a potent analgesic opioid used extensively for pain treatment. During the last decade, global consumption grew more than 4-fold. However, molecular mechanisms elicited by morphine are not totally understood. Thus, a growing literature indicates that there are additional actions to the analgesic effect. Previous studies about morphine and oxidative stress are controversial and used concentrations outside the range of clinical practice. Therefore, in this study, we hypothesized that a therapeutic concentration of morphine $(1 \mu \mathrm{M})$ would show a protective effect in a traditional model of oxidative stress. We exposed the C6 glioma cell line to hydrogen peroxide $\left(\mathrm{H}_{2} \mathrm{O}_{2}\right)$ and/or morphine for $24 \mathrm{~h}$ and evaluated cell viability, lipid peroxidation, and levels of sulfhydryl groups (an indicator of the redox state of the cell). Morphine did not prevent the decrease in cell viability provoked by $\mathrm{H}_{2} \mathrm{O}_{2}$ but partially prevented lipid peroxidation caused by $0.0025 \% \mathrm{H}_{2} \mathrm{O}_{2}$ (a concentration allowing more than $90 \%$ cell viability). Interestingly, this opioid did not alter the increased levels of sulfhydryl groups produced by exposure to $0.0025 \% \mathrm{H}_{2} \mathrm{O}_{2}$, opening the possibility that alternative molecular mechanisms (a direct scavenging activity or the inhibition of NAPDH oxidase) may explain the protective effect registered in the lipid peroxidation assay. Our results demonstrate, for the first time, that morphine in usual analgesic doses may contribute to minimizing oxidative stress in cells of glial origin. This study supports the importance of employing concentrations similar to those used in clinical practice for a better approximation between experimental models and the clinical setting.
\end{abstract}

Key words: Morphine; Glia; Oxidative stress; Hydrogen peroxide; Lipid peroxidation; Opiod

\section{Introduction}

Morphine is a potent analgesic opioid extensively used for pain treatment in diverse pathologies and clinical situations (cancer, neuropathic myalgia, emergencies, assisted ventilation, and anesthesia, among others). Although chronic treatment with opioid drugs leads to tolerance and dependence, morphine has proven to be one of the most potent and efficient analgesic drugs in clinical practice, becoming a major option for the treatment of moderately severe to severe pain. Thus, according to the most recent report of the International Narcotics Control Board of the United Nations (1), global consumption of morphine for medical and scientific purposes rose considerably during the period from 1992 to 2011. During that time, morphine consumption grew more than 4-fold (from 10 to 42 tons) throughout the world. In Brazil, the consumption of this opioid also increased during the same period, reaching 106 defined daily doses for statistical purposes consumed per million inhabitants per day in 2009-2011 (1).

However, the molecular mechanisms elicited by morphine are not totally understood. This molecule is able to activate a family of metabotropic receptors $(\mu-, \delta$-, and $\kappa$-type opioid receptors). Endogenous opioids are found in many structures of the central nervous system (CNS) and spinal cord (reviewed in Ref. 2). Classically, the analgesic effect of morphine is mainly attributed to $\mu$ receptor activation, leading to an inhibition of calcium influx in presynaptic neurons and an increase in potassium conductance in postsynaptic neurons, among other effects. Additionally, opioid receptors are also localized in cells of glial origin, especially microglia and astrocytes (a feature preserved even in gliomas like the $\mathrm{C} 6$ cell line) where they may be involved in neurotrophism during development and under pathological conditions (3). 
Interestingly, there is a growing literature supporting additional actions for morphine, as in the case of the role played by the opioid in oxidative stress (4-13). Oxidative stress is the disequilibrium between free radical generation and elimination (a free radical is a very reactive molecule with an unpaired electron). This excess of free radicals [usually reactive oxygen species (ROS)] reacts with macromolecules (DNA, proteins, and lipids) as a molecular mechanism underlying many pathologies and physiological processes. Interaction with lipids is especially deleterious for the membranes, triggering the selfpropagated process of lipid peroxidation. To prevent the damage caused by ROS, cells rely on enzymatic [e.g., superoxide dismutase (SOD) or glutathione peroxidase $(\mathrm{GPx})]$ and nonenzymatic antioxidant systems. Among the latter, glutathione stands out as a major scavenger molecule, representing the most common low molecular weight compound containing sulfhydryl groups in mammalian cells (with levels as high as millimolar for the majority of cells) (14). Thus, the content of sulfhydryl groups can be considered an indicator of the redox state of the cell.

Previous studies of the relationship between morphine and oxidative stress are not very abundant, and the results describing the pro-oxidant or antioxidant roles of the opioid are contradictory (4-13).

In addition to that controversy, all of those studies used doses of morphine outside the therapeutic range used in clinical practice (i.e., plasma levels of 16-364 ng/ $\mathrm{mL}$ ) (15) and, to date, no investigations have analyzed the effects of therapeutic concentrations of morphine in oxidative stress.

Therefore, in this study, we hypothesized that a therapeutic concentration of morphine $(1 \mu \mathrm{M})$ would show a protective effect in a traditional model of oxidative stress [exposure to hydrogen peroxide $\left(\mathrm{H}_{2} \mathrm{O}_{2}\right)$ ] in the $\mathrm{C} 6$ glioma cell line.

\section{Material and Methods}

\section{Cell culture}

The rat glioma C6 cell line was purchased from American Type Culture Collection (ATCC, USA) and maintained at $37^{\circ} \mathrm{C}$ and $5 \% \mathrm{CO}_{2}$ in Dulbecco's modified Eagle's medium (DMEM) with $10 \%$ fetal bovine serum, $100 \mathrm{U} / \mathrm{mL}$ penicillin, and $100 \mu \mathrm{g} / \mathrm{mL}$ streptomycin. Approximately $1.5 \times 10^{5}$ cells were seeded and maintained at $37^{\circ} \mathrm{C}$ for $24 \mathrm{~h}$ before exposure to $\mathrm{H}_{2} \mathrm{O}_{2}$ and/or morphine.

\section{Treatment}

$\mathrm{H}_{2} \mathrm{O}_{2}(30 \%)$ was diluted in DMEM to final concentrations of 0 to $0.005 \%$. Morphine sulfate $(10 \mathrm{mg} / \mathrm{mL})$, kindly donated by Cristália (Brazil), was also diluted in DMEM to $1 \mu \mathrm{M}(285.34 \mathrm{ng} / \mathrm{mL})$. The $\mathrm{C} 6$ cell line was then incubated with $\mathrm{H}_{2} \mathrm{O}_{2}$ and/or morphine for $24 \mathrm{~h}$.

\section{Cell viability}

Cell viability was assessed as previously described by Mosmann (16). After the treatment, cells were washed twice with phosphate-buffered saline (PBS) and incubated for $2 \mathrm{~h}$ with $5 \mathrm{mg} / \mathrm{mL}$ 4,5-dimethylthiazol bromide diphenyltetrazolium (MTT). Absorbance of the samples was measured at $570 \mathrm{~nm}$ and cell viability is reported as the percentage of reduced MTT compared to that of the control group.

\section{Assay of lipid peroxidation}

Lipid peroxidation was evaluated by measuring malondialdehyde (MDA) levels as described elsewhere (17). Briefly, after treatment, cells were homogenized in a solution containing $0.1 \%$ thiobarbituric acid, $0.25 \mathrm{M} \mathrm{HCl}$, and $15 \%$ trichloroacetic acid. Samples were then incubated for $15 \mathrm{~min}$ at $70^{\circ} \mathrm{C}$. Finally, absorbance was measured at $535 \mathrm{~mm}$ and compared to that of standard concentrations of MDA.

\section{Assay of sulfhydryl groups}

Levels of compounds containing sulfhydryl groups were assayed by the method described by Ellman (18) using the selective reaction of these groups with 5,5'dithio-bis(2-nitrobenzoic acid (DTNB or Ellman's reagent). Treated cells were homogenized in ice-cold PBS with $1 \mathrm{mM}$ EDTA and $0.1 \%$ sodium dodecyl sulfate and centrifuged for $5 \mathrm{~min}$ at $750 \mathrm{~g}$. Supernatants were treated for $5 \mathrm{~min}$ with $5 \mathrm{mM}$ DTNB and absorbance was evaluated at $412 \mathrm{~nm}$.

\section{Assay of protein content}

Protein quantities in the samples were assayed using the method described by Bradford in 1976 (19). Thus, after correcting for protein concentration, the results of lipid peroxidation and sulfhydryl groups are reported as percentages of the control group values.

Assay of direct scavenging activity of $\mathrm{H}_{2} \mathrm{O}_{2}$ molecules

To evaluate the possibility of direct scavenging of $\mathrm{H}_{2} \mathrm{O}_{2}$ by morphine, the protocol described by Gülçin et al. (5) was carried out. Briefly, morphine (1-100 $\mu \mathrm{M})$ was added to a solution of $4 \mathrm{mM} \mathrm{H}_{2} \mathrm{O}_{2}$ in PBS. After $10 \mathrm{~min}$, absorbance was measured at $230 \mathrm{~nm}$ and the percentage of scavenged $\mathrm{H}_{2} \mathrm{O}_{2}$ was calculated according to the following formula: percent scavenged $\mathrm{H}_{2} \mathrm{O}_{2}=\left[\left(\mathrm{A}_{0}-\mathrm{A}_{1}\right)\right.$ / $\left.A_{0}\right] \times 100$, where $A_{0}$ is the absorbance of the control group and $A_{1}$ is the absorbance in the presence of morphine.

\section{Statistical analysis}

Statistical analysis was performed using the BIOESTAT 5.0 software (Brazil; http://www.mamiraua.org.br/pt-br/ downloads/programas/). Initially, the Gaussian distribution of the data was tested by the Kolmorov-Smirnoff method with $\mathrm{P}<0.05$ considered to be significant. Subsequently, all groups were analyzed with ANOVA and the Tukey post hoc 


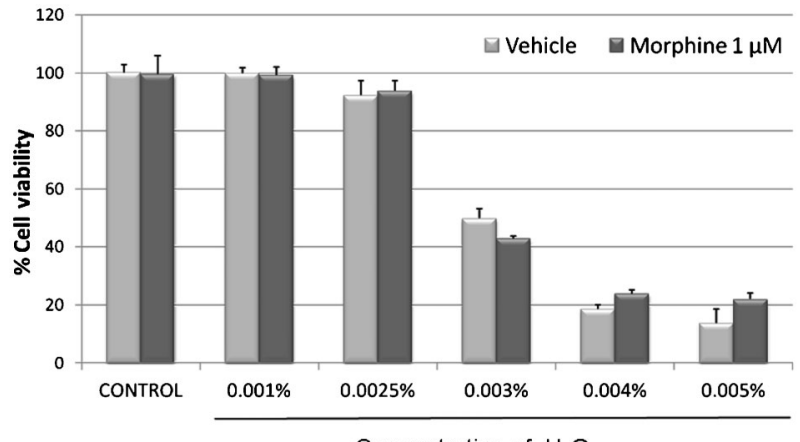

Concentration of $\mathrm{H}_{2} \mathrm{O}_{2}$

Figure 1. Cell viability of $\mathrm{C} 6$ cell line exposed to increasing concentrations of hydrogen peroxide $\left(\mathrm{H}_{2} \mathrm{O}_{2}\right)$ and/or $1 \mu \mathrm{M}$ morphine for $24 \mathrm{~h}$. Data are reported as means \pm SE. No significant differences were detected in groups incubated with the same concentration of $\mathrm{H}_{2} \mathrm{O}_{2}$ (ANOVA).

test, when appropriate. Values of $\mathrm{P}<0.05$ were considered to be statistically significant.

\section{Results}

\section{Cell viability}

Exposure to increasing concentrations of $\mathrm{H}_{2} \mathrm{O}_{2}$ reduced cell viability of the $\mathrm{C} 6$ cell line in a concentrationdependent manner (Figure 1). No significant changes in C6 cultures were detected when cells were incubated with 1 to $10 \mu \mathrm{M}$ morphine (data not shown). Cotreatment with $1 \mu \mathrm{M}$ morphine did not show significant differences in viability when compared with that of cells incubated only with $\mathrm{H}_{2} \mathrm{O}_{2}$. For subsequent experiments, a concentration of $0.0025 \% \mathrm{H}_{2} \mathrm{O}_{2}$ (approximately $735 \mu \mathrm{M}$ ) was chosen, allowing more than $90 \%$ cell viability.

\section{Lipid peroxidation}

Incubation of cells with $0.0025 \% \mathrm{H}_{2} \mathrm{O}_{2}$ raised the level of lipid peroxidation more than three times that of the control group (Figure 2). Interestingly, morphine partially

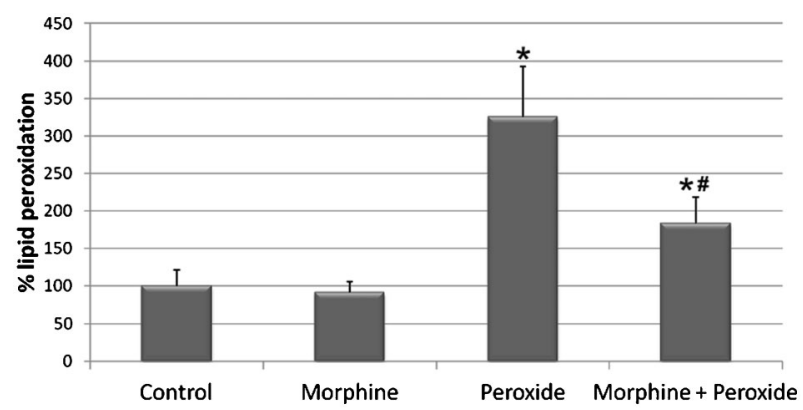

Figure 2. Lipid peroxidation of $\mathrm{C} 6$ cell line exposed to $0.0025 \%$ hydrogen peroxide $\left(\mathrm{H}_{2} \mathrm{O}_{2}\right)$ and/or $1 \mu \mathrm{M}$ morphine for $24 \mathrm{~h}$. Data are reported as means $\pm S E$. ${ }^{*} \mathrm{P}<0.05$ vs control and morphine groups; ${ }^{\mathrm{P}}<0.05$ vs peroxide group (ANOVA and Tukey test). protected the cells, avoiding $44 \%$ of this increase.

\section{Levels of sulfhydryl groups}

In all cases, exposure to $0.0025 \% \mathrm{H}_{2} \mathrm{O}_{2}$ enhanced the levels of compounds containing sulfhydryl groups in the C6 cells by about 20\% (Figure 3 ). However, cotreatment with morphine did not prevent this increase, and no significant differences were detected between cells treated with $\mathrm{H}_{2} \mathrm{O}_{2}$ and those cotreated with morphine.

\section{Scavenging activity of $\mathrm{H}_{2} \mathrm{O}_{2}$ molecules}

Morphine at 1 and $10 \mu \mathrm{M}$ concentrations did not change the levels of $\mathrm{H}_{2} \mathrm{O}_{2}$ (Figure 3, insert). Interestingly, $100 \mu \mathrm{M}$ morphine was able to significantly scavenge (about $26.5 \%$ ) these molecules in vitro.

\section{Discussion}

This study showed, for the first time, that a therapeutic concentration of morphine significantly reduced oxidative stress in cells of glial origin exposed to $\mathrm{H}_{2} \mathrm{O}_{2}$ (Figures 1 and 2).

The concentration of the opioid used in the present study ( $1 \mu \mathrm{M}$ or $285.34 \mathrm{ng} / \mathrm{mL}$ ) is near the upper limit of human therapeutic concentrations. For example, patients with chronic treatment for pain management usually show plasma levels of morphine ranging from 16 to $364 \mathrm{ng} / \mathrm{mL}$ (15). The relatively high liposolubility of morphine allows it to easily cross the blood-brain barrier, making the levels of the opioid in nervous tissue very similar to those found in the blood.

In addition, this concentration (or 10 times higher) did not affect the viability of the C6 cells (data not shown). This fact was in agreement with results previously described, in which human fetal astrocytes exposed to $1 \mu \mathrm{M}$ morphine did not develop apoptotic processes such

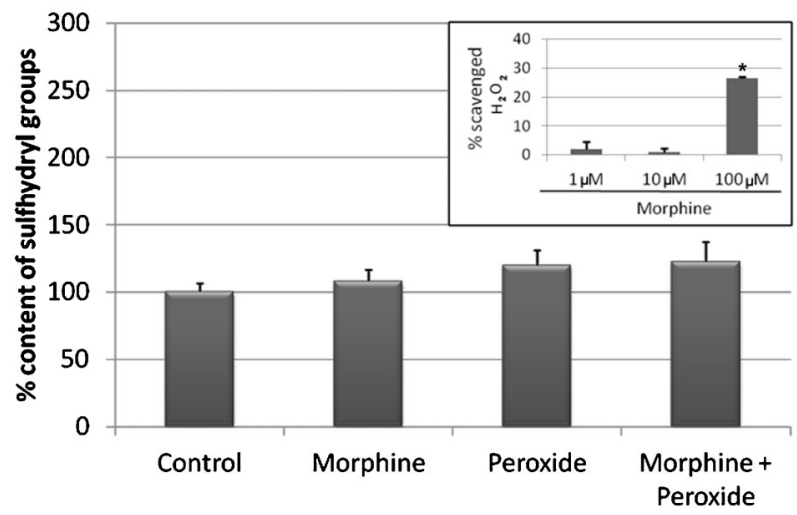

Figure 3. Content of sulfhydryl groups in the $\mathrm{C} 6$ cell line exposed to $0.0025 \%$ hydrogen peroxide $\left(\mathrm{H}_{2} \mathrm{O}_{2}\right)$ and/or $1 \mu \mathrm{M}$ morphine for $24 \mathrm{~h}$. The insert shows levels of scavenged $\mathrm{H}_{2} \mathrm{O}_{2}$ in vitro in the presence of $1-100 \mu \mathrm{M}$ morphine. Data are reported as means $\pm \mathrm{SE}$. ${ }^{*} \mathrm{P}<0.05$ vs all groups (ANOVA and Tukey test). 
as those found in neurons and microglia exposed to the same concentration of the opioid (20).

Exposure to $\mathrm{H}_{2} \mathrm{O}_{2}$ is a traditional model of oxidative stress for cells of CNS origin. In our study, the concentrationresponse curve fitted to a sigmoid curve was designed to calculate the $50 \%$ lethal concentration value $(0.0032 \%)$ characterizing the toxicity of $\mathrm{H}_{2} \mathrm{O}_{2}$ for the $\mathrm{C} 6$ cell line (Figure 1). Taking into account the cell viability data, a concentration of $\mathrm{H}_{2} \mathrm{O}_{2}(0.0025 \%)$ allowing more than $90 \%$ viable cells after $24 \mathrm{~h}$ of incubation was selected for all subsequent experiments.

This latter concentration of $\mathrm{H}_{2} \mathrm{O}_{2}$ did not affect cell viability when compared with that of the control group (Figure 1), but provoked a significant increase in levels of lipid peroxidation (Figure 2). Treatment with morphine reduced this increase by $44 \%$, showing a significant antioxidant activity with a therapeutic dose.

Previous studies with morphine that have analyzed markers of oxidative stress are not very common, and the role attributed to the opioid remains, at the very least, controversial.

Studies indicating a pro-oxidant activity of morphine used high doses and/or evaluated oxidative stress as a mechanism associated with tolerance and/or dependence on the opioid $(7,9,11-13)$. Exposure to increased concentrations of morphine (as high as $6 \mathrm{mM}$ ) has already been used as a model of neuronal damage by oxidative stress in both in vivo and in vitro studies (including the C6 cell line) (7,11-13). Morphine intoxication decreased the activity of antioxidant enzymes (SOD and GPx, among others) and induced apoptosis and glial activation. Glial activation closely associated with oxidative stress was also observed in opioid tolerance/dependence (9) with increased levels of lipid peroxidation and reduced levels of glutathione. Nevertheless, the doses of morphine included in those studies were much higher than those usually used in humans for therapeutic treatment of pain.

On the other hand, a number of studies using lower concentrations of morphine (but still outside the therapeutic range) show a possible antioxidant role for the opioid $(4-6,8,10)$. Indeed, primary cultures (neurons and/ or glial cells) and cell lines such as SHSY5Y (derived from a human neuroblastoma cell line) and C6 were protected by the opioid in models of neurotoxicity produced by peroxynitrite donors, glutamate, lipopolysaccharide (LPS), and 1-methyl-4-phenylpyridinium incubation $(4,6,8)$.

Therefore, our hypothesis is that high doses of morphine may be pro-oxidative, but therapeutic doses, such as that used in this study, would have a significant antioxidant effect (especially in glia).

One interesting observation is that the antioxidant effects of morphine in previous studies were registered in isolated structures (mitochondria), in the presence of antagonists of opioid receptors or also for the synthetic enantiomer $d$-morphine (which does not bind to the $\mu$ opioid receptor), demonstrating that the antioxidant activity of morphine is independent of opioid receptors $(4,6,8)$. Reinforcing this idea, selective ligands for $\mu-, \delta-$, and $\kappa$-type opioid receptors did not show any of the neuroprotective effects of morphine $(4,6)$.

In those studies, morphine reduced DNA fragmentation, stabilized mitochondrial permeability and function, inhibited microglial activation, and recovered glutathione levels $(4,6,8,10)$. Detection of alterations in glutathione levels with morphine treatment is frequent even at higher concentrations of the opioid $(7,9,12,13)$ and can be evaluated by the quantitation of levels of sulfhydryl groups. Reduced glutathione is the major intracellular compound containing these groups.

Surprisingly, our results about possible molecular mechanisms of this antioxidant effect of morphine showed that protection against lipid peroxidation (Figure 2) was independent of both a possible influence of the levels of sulfhydryl groups (morphine did not reduce the levels increased by $\mathrm{H}_{2} \mathrm{O}_{2}$ ) and a significant scavenger effect of $\mathrm{H}_{2} \mathrm{O}_{2}$ molecules with a $1 \mu \mathrm{M}$ concentration of the opioid (Figure 3 ). Although no scavenging activity by morphine was shown with a $1 \mu \mathrm{M}$ concentration, a significant decrease in $\mathrm{H}_{2} \mathrm{O}_{2}$ molecules was detected with higher concentrations of the opioid, similar to that reported previously (5). Additionally, a strong scavenging activity of morphine with compounds other than $\mathrm{H}_{2} \mathrm{O}_{2}$ has already been reported $(4,5)$. Thus, an alternative molecular mechanism to explain the protection exerted by the opioid could be that of a direct scavenger effect of free radicals other than $\mathrm{H}_{2} \mathrm{O}_{2}$ molecules.

Nevertheless, other mechanisms must not be discarded. The research of Qian et al. (8) showed that morphine was not capable of protecting primary cultures (neurons and glial cells) from mice deficient in the catalytic subunit of NADPH oxidase (a key enzyme required for the production of ROS) against LPS incubation, demonstrating the importance of this enzyme in the protective effect of the opioid. Also, morphine attenuated the translocation of a cytosolic component of NADPH oxidase $\left(p 47^{\text {phox }}\right)$ to the cell membrane, a process necessary for assembling into an ative enzyme. Considering these results, the authors pointed to inhibition of NADPH oxidase as an essential molecular mechanism for the effect of morphine (8). Thus, reduced activity of this enzyme could be another possible explanation for the antioxidant effect of morphine found in our study. Additional studies must be carried out to elucidate the exact molecular mechanism underlying these effects.

This is the first study to analyze the effects of a therapeutic concentration of morphine in an in vitro model of oxidative stress. Our results demonstrated that morphine, in usual analgesic doses, may contribute to minimizing oxidative stress in glial cells. More studies employing concentrations similar to those used in clinical practice are necessary for a better understanding of the applicability of experimental models to the clinical setting. 


\section{Acknowledgments}

The authors thank Cristália (Brazil) for the kind donation of morphine. Research supported by CNPq (\#303110/ 2010-4 and \#478580/2012-6). A. Costa-Malaquias thanks

\section{References}

1. International Narcotics Control Board (INCB). Report 2012. Estimated World Requirements for 2013 - Statistics for 2011. New York: United Nations Publication; 2012.

2. Laux-Biehlmann A, Mouheiche J, Veriepe J, Goumon Y. Endogenous morphine and its metabolites in mammals: history, synthesis, localization and perspectives. Neuroscience 2013; 233: 95-117, doi: 10.1016/j.neuroscience. 2012.12.013.

3. Bohn LM, Belcheva MM, Coscia CJ. Evidence for kappaand mu-opioid receptor expression in $\mathrm{C} 6$ glioma cells. $J$ Neurochem 1998; 70: 1819-1825, doi: 10.1046/j.1471-4159. 1998.70051819.x.

4. Kanesaki T, Saeki M, Ooi Y, Suematsu M, Matsumoto K, Sakuda M, et al. Morphine prevents peroxynitrite-induced death of human neuroblastoma SH-SY5Y cells through a direct scavenging action. Eur J Pharmacol 1999; 372: 319324, doi: 10.1016/S0014-2999(99)00206-X.

5. Gülçin I, Beydemir S, Alici HA, Elmastas M, Buyukokuroglu ME. In vitro antioxidant properties of morphine. Pharmacol Res 2004; 49: 59-66, doi: 10.1016/j.phrs.2003.07.012.

6. Lee J, Kim MS, Park C, Jung EB, Choi DH, Kim TY, et al. Morphine prevents glutamate-induced death of primary rat neonatal astrocytes through modulation of intracellular redox. Immunopharmacol Immunotoxicol 2004; 26: 17-28, doi: 10.1081/IPH-120029941.

7. Guzman DC, Vazquez IE, Brizuela NO, Alvarez RG, Mejia $\mathrm{GB}$, Garcia EH, et al. Assessment of oxidative damage induced by acute doses of morphine sulfate in postnatal and adult rat brain. Neurochem Res 2006; 31: 549-554, doi: 10.1007/s11064-006-9053-7.

8. Qian L, Tan KS, Wei SJ, Wu HM, Xu Z, Wilson B, et al. Microglia-mediated neurotoxicity is inhibited by morphine through an opioid receptor-independent reduction of NADPH oxidase activity. J Immunol 2007; 179: 1198-1209.

9. Ozmen I, Naziroglu M, Alici HA, Sahin F, Cengiz M, Eren I. Spinal morphine administration reduces the fatty acid contents in spinal cord and brain by increasing oxidative stress. Neurochem Res 2007; 32: 19-25, doi: 10.1007/s11064006-9217-5.

10. Feng $Y$, Lu $Y$, Lin $X$, Gao $Y$, Zhao Q, Li W, et al. Endomorphins and morphine limit anoxia-reoxygenation-induced
FAPESPA for his grant. J.L.M. Nascimento, A.M. Herculano, and M.E. Crespo-López thank CNPq for their grants. The authors also thank Pró-Reitoria de Pesquisa/ Universidade Federal do Pará (PROPESP/UFPA) for support.

brain mitochondrial dysfunction in the mouse. Life Sci 2008; 82: 752-763, doi: 10.1016/j.lfs.2008.01.004.

11. Zhou J, Li Y, Yan G, Bu Q, Lv L, Yang Y, et al. Protective role of taurine against morphine-induced neurotoxicity in C6 cells via inhibition of oxidative stress. Neurotox Res 2011; 20: 334-342, doi: 10.1007/s12640-011-9247-x.

12. Rozisky JR, Laste G, de Macedo I, Santos VS, Krolow R, Noschang $C$, et al. Neonatal morphine administration leads to changes in hippocampal BDNF levels and antioxidant enzyme activity in the adult life of rats. Neurochem Res 2013; 38: 494-503, doi: 10.1007/s11064-012-0941-8.

13. Abdel-Zaher AO, Mostafa MG, Farghaly HS, Hamdy MM, Abdel-Hady $\mathrm{RH}$. Role of oxidative stress and inducible nitric oxide synthase in morphine-induced tolerance and dependence in mice. Effect of alpha-lipoic acid. Behav Brain Res 2013; 247: 17-26, doi: 10.1016/j.bbr.2013.02.034.

14. Neumann PB, Henriksen H, Grosman N, Christensen CB. Plasma morphine concentrations during chronic oral administration in patients with cancer pain. Pain 1982; 13: 247252, doi: 10.1016/0304-3959(82)90014-8.

15. Sen C. Nutritional biochemistry of cellular glutathione. J Nutr Biochem 1997; 8: 660-672, doi: 10.1016/S0955-2863(97) 00113-7.

16. Mosmann T. Rapid colorimetric assay for cellular growth and survival: application to proliferation and cytotoxicity assays. J Immunol Methods 1983; 65: 55-63, doi: 10.1016/ 0022-1759(83)90303-4.

17. Bird RP, Draper HH. Comparative studies on different methods of malonaldehyde determination. Methods Enzymol 1984; 105: 299-305, doi: 10.1016/S0076-6879 (84)05038-2.

18. Ellman GL. Tissue sulfhydryl groups. Arch Biochem Biophys 1959; 82: 70-77, doi: 10.1016/0003-9861(59)90090-6.

19. Bradford MM. A rapid and sensitive method for the quantitation of microgram quantities of protein utilizing the principle of protein-dye binding. Anal Biochem 1976; 72: 248-254, doi: 10.1016/0003-2697(76)90527-3.

20. Hu S, Sheng WS, Lokensgard JR, Peterson PK. Morphine induces apoptosis of human microglia and neurons. Neuropharmacology 2002; 42: 829-836, doi: 10.1016/S00283908(02)00030-8. 